\title{
The wheeled cauldrons and the wine
}

\author{
GAD RAUSING*
}

\begin{abstract}
Grapes appear rather early in temperate Europe: even in the cool north of Sweden, their pips occur in the Neolithic: With grapes go wine, and with wine go the artefacts of wine, amongst them the cauldron on wheels - a grand and an odd artefact type of Bronze Age Europe.
\end{abstract}

\section{The wheeled cauldron}

More than a century ago, in 1895 , a farmer at Skallerup (Udby parish, Praestö Amt, Bårse Herred, Zealand) in Denmark plundered one of the barrows of the area, finding a rich cremation grave which he damaged badly (Aner et al. 1976: plates 142, 143). The burnt bones had been buried in a foreign bronze vessel, a 'wheeled cauldron' from somewhere in central Europe, probably from present-day Hungary or Romania. H.C. Broholm (1952) describes the vessel:

An undercarriage of bronze, with four 4-spoked wheels, supports a wrought bronze cauldron with a round body, fitted with a hollow pedestal. The cauldron is decorated with rows of dots, raised by embossing from the inside.

(Actually the cauldron consists of three pieces: top, bottom and foot, each of chased sheet bronze, rivetted together and the joints filled with rosin.]

The rim of the cauldron is bent out to the horizontal, supported by four twisted bronze rods rivetted to the sides of the vessel, and decorated with thin, lancet-shaped rattle-plates hung in short chains, rivetted to the rim. Two bronze rods are in addition rivetted to the undercarriage and terminate in figures of birds. Altogether four 'wheeled cauldrons' are known from North and Central Europe, all imported articles though there is still some disagreement concerning their place of origin. It seems most probable, however, that the Skallerup cauldron originated in Hungary.

Broholm dates this find to the early Bronze Age.

The Skallerup grave also contained a sword, a knife, a razor and a golden bracelet, woollen textiles (most probably a cloak), a cow's hide (the conventional shroud of the time), and ornamented fragments of horn, probably the remains of a drinking horn. A few generations earlier, before cremation had become dominant, when the dead were still buried, a big pot or sometimes even a bronze vessel was normally part of the grave-goods, a vessel containing the drink to refresh the defunct on his long journey. Even when the dead were cremated this large vessel remained the most important gravegift, now used to contain the burnt bones. Apparently it was still thought to contain a symbolic liquid, since the drinking cup still went with it. Although this piece (and its counterparts at Milavec, Ystad and Peccatel) have been called 'wheeled cauldrons', they are actually 'wagons carrying approximately biconical vessels, mounted on cylindrical or conical pedestals'.

Was the undercarriage intended to represent two canoes, mounted on wheels?

Similar vessels have been found at Ystad in Sweden, at Milavec in Bohemia and at Peccatel in Mecklenburg, Germany, all dating from the early Bronze Age, i.e. the centuries between roughly 1800 and 1100 bc. In 1970 another kettle-wagon, closely resembling that from Skallerup, came to light in a cremation grave at Acholshausen, near Ochsenfurt, Germany, together with weapons suggesting 'Mycenean connections' (Pescheck 1975). This grave has been dated to about $1250 \mathrm{BC}$ (Schutz 1983: plate 2c). The Acholshausen vessel - decorated in a way that makes it quite clear that it represents a wickerwork basket - is slightly pearshaped, with a large opening and a wide, low cylindrical neck. The central framework of this 'wagon' consists of two beams, of square section, crossing each other to form a small surface, on which stands the conical frame supporting the bronze vessel. The ends of the beams curve up, forming duck protomes. It thus differs slightly from that of the Skallerup wagon, which con-

* Case Postale 22, 1820 Territet, Switzerland.

Received 14 January 1997, accepted 25 March 1997, revised 9 June 1997.

ANTIQUTTY 71 (1997): 994-9 
sists of two parallel 'canoes', joined by the wheelshafts, around which the wheels turn.

Clay wheels found at other sites suggest that similar vessels on wheels were also made of organic materials, such as have not survived.

As noted, all through the late Neolithic and the early Bronze Age, custom required the defunct to be given a large vessel (of clay, wood or birch-bark) as a container for his drink, as well as a drinking cup. It seems likely that the drink afforded would not usually have been wine, but the find from Egtved proves that also local brews were acceptable. Brewed from wheat and honey, flavoured with cranberries and bog myrtle, they could be potent indeed. This was, in fact, an early version of mead, of a power comparable to a dry sherry.

\section{Wine in early Europe}

Did bronze-age Scandinavians also drink wine? The vine, Vitis vinifera, is closely related to a group of wild and segetal wine forms distributed over Europe and western Asia. Formerly botanists regarded these old-world wild grapes as an independent species, Vitis sylvestris; today most botanists regard them as a wild race of the cultivated group. Sylvestris grapes differ from the cultivated varieties by their relatively small berries; although usually acid they can be used for the preparation of wine. Just as proto-farmers first collected the seeds of wild grasses, they probably also collected the berries of Vitis sylvestris, whether for immediate consumption or to make wine. In doing so, they probably also improved conditions for the plants, later actively to cultivate them. Over a long period of years this selective breeding, intentional or unintentional, of Vitis sylvestris resulted in Vitis vinifera.

Although Zohary (1995) suggests that vines were cultivated and wine produced already in the 7th millennium BC we know of no certain evidence for even Vitis sylvestris being cultivated so early; but no doubt the vine was one of the early cultivars, and grapes seem to have been known in Scandinavia in the late 5th millennium and in Britain somewhat later.

Three grape-pip impressions have been found in sherds of early Neolithic pots from Sweden - at Mogetorp, Ôstra Vrå and Moäng, all within the present-day town of Katrineholm - and Vitis_pollen of the same period found at Prästö in Denmark. The morphological characteristics of the pips represented by the casts from the three sites are not very clear, nor could they be expected to be at such an early time, about $4200 \mathrm{BC}$.

At that time the summer temperature was some $2 \cdot 5^{\circ}$ Celsius higher than it is today, and also in the Bronze Age (c. 1800-500 BC) both the yearly average temperature and the summer temperature was appreciably higher than today. In the mountains the tree-line was about $300 \mathrm{~m}$ higher than in our days, and several animals and plants which now reach their northern limit in north Germany flourished up to central Sweden. Small wonder that grapes could be cultivated at $58^{\circ} 59^{\prime}$ North!

With minor variations, this mild climate lasted until the end of the Bronze Age, around $500 \mathrm{BC}$; remarkably enough, we have no further finds from Scandinavia of grapes or of vine pollen from this long period of time.

Also in Britain both the average summer temperature and the average yearly temperature were considerably higher than today's. A rubbish pit at the causewayed enclosure site of Stepleton near Hambledon Hill in Dorset yielded one pip which gave an uncalibrated radiocarbon date of $4660 \pm 80$ b.p.; so the pip from Stepleton and those from Sweden are of roughly the same age. I can but quote Jones \& Legge (1987: 454):

The occurrence of a single grape of apparently domesticated form at the Stepleton causewayed enclosure tells us little about the status of this species in the neolithic diet. Other common cultigens of that time, such as emmer wheat, require parching as part of the processing needed before consumption. With a simple technology this and other processes commonly resulted in the charring of seeds that then survive in archaeological sediments. Grapes are a species that require no such preparation before consumption, and their chances of preservation by charring are much reduced because of this. It is possible that Vitis was regularly cultivated during the Neolithic of Britain; very few neolithic sites have been extensively sampled for charred plant remains, and much remains to be learned of the cultigens from that period.

This also holds true for Scandinavia, for north Germany and for Poland - but evidence $e$ silentio carries no weight!

Definite signs of Vitis cultivation first appear in Jericho, in the early Bronze Age, in layers dating from about $3200 \mathrm{BC}$, in strata about a thousand years younger than the Swedish finds and that from Stepleton.

Although Hansen (1988; 39-52) does not accept the evidence for the cultivation of vines 
at Sitagroi in the 4 th millennium, there is clear evidence of grapes being grown, and pressed, at Lerna IV, at MM Knossos and Phaistos as well as at several MH sites. The special equipment for producing wine from grapes cannot be discerned in the archaeological material until Minoan times, when linear B texts from Knossos and from Pylos refer to orchards and vineyards (Dickinson 1994: 46). These texts also refer to figs, olives, olive oil and wine.

The oldest actual find of wine or, rather, of deposits left by decomposing wine, is that from Godin Tepe, in Iran, whose Period V covers the period 3500-2900 $\mathrm{BC}$, contemporary with the late Uruk Period of Mesopotamia. A building from the beginning of Period $V$ yielded two jars, each capable of holding about 35 litres, with traces left by a liquid on their inside. Infra-red spectroscopic analysis showed this to be mainly tartaric acid and tartaric salts. In nature, tartaric acid is found almost exclusively in grapes (Badler 1990: 32). It seems more than likely that these were jars which had once been used for storing wine, proving wine to have been produced and consumed at Godin Tepe already by the end of the 4 th millennium. The precautions that seem to have been taken with these jars, stoppering them and storing them on their sides, also suggest that they did contain wine.
In the 18th century BC the palace at Knossos was rebuilt, presumably after an earthquake. This was when the great pithoi were installed, vessels with a capacity of several hundred litres. Some, containing olive pips, were undoubtedly used for storing olives or olive oil, others seem to have been used for fermenting grape juice into wine. The hundreds of large pithoi in palace store-rooms in Knossos and Malia, their height ranging from some $66 \mathrm{~cm}$ to more than $200 \mathrm{~cm}$ (Cullen \& Keller 1990), had the same function as did those from 16th-century and later installations in Peru (Rice 1996). At first sight it might appear that the very large openings of these huge pithoi might be difficult to seal properly and thus make them unsuitable for the storage of wine or even for the production of wine. It appears that a thin layer of olive oil on the surface of the oxygen-sensitive water-base wine is sufficient to protect it from oxygen.

To be sure, the juice could, and can, be fermented in ordinary household vessels, but those were almost invariably rather small, fit for the production of wine only for 'family use', whereas the 'storage pithoi' usually had a capacity of several hundred litres, the same as that of the fermentation vessels used in Roman times. The absence of such large pots thus does not prove

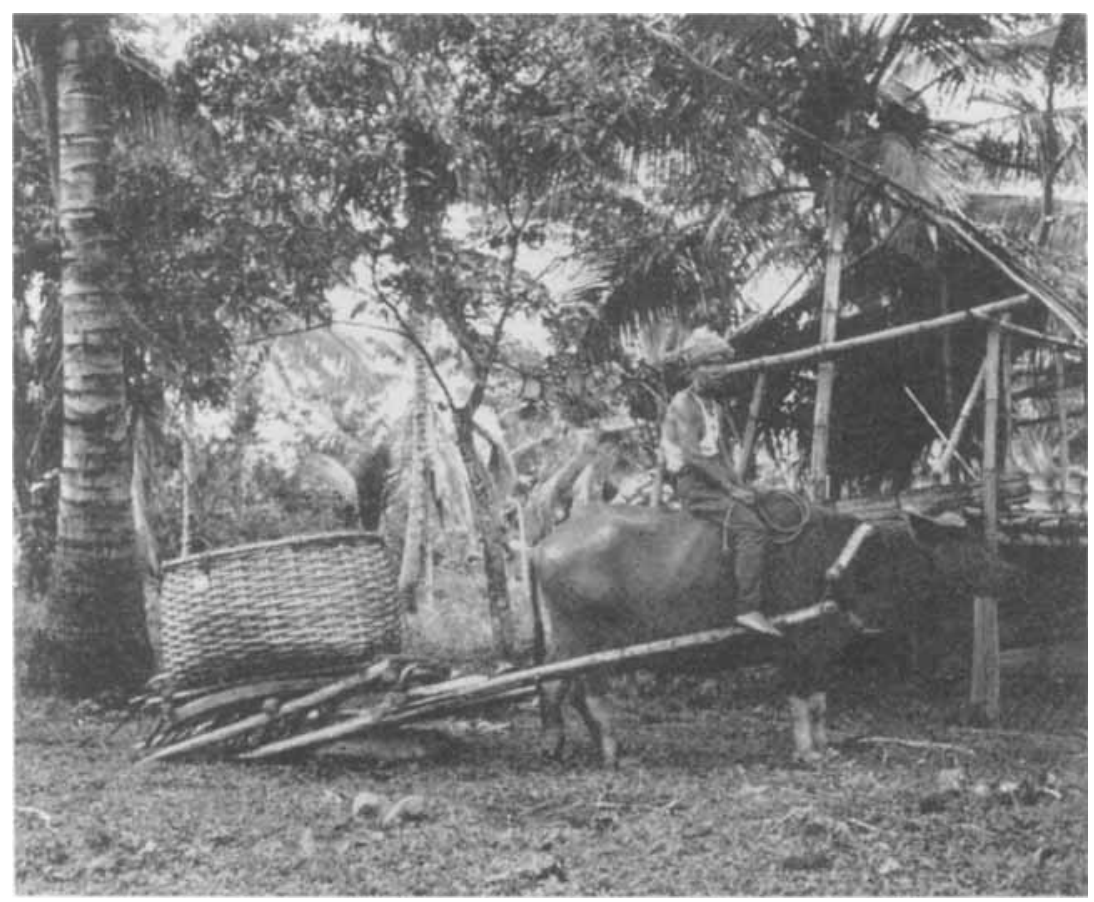

FIGURE 1. In the 1930 s in northern Sweden, exactly the same type of sled was used, though horse-drawn, to transport tents and supplies across the mountains.

(Arbejdsmark 1970: 36.) 
wine not to have been produced, since the grape juice could be fermented also in wooden vessels and perhaps even in wax-coated leather sacks; where they do occur, the presence of such huge pithoi suggests that wine was made. In recent times European vintners have usually fermented their juice in wooden vessels, but in an emergency, almost any vessel could be used, as suggested by Leif Erikssons Saga. This tells us that, when Leif's man Tyrker had found vines with grapes, 'they loaded the dinghy with grapes'. This passage has often been ridiculed and taken to 'prove' that the saga is not worth taking seriously. Actually the passage tells us that there were enough grapes for a great amount of wine to be made, that the grapes could be pressed, and the juice could be fermented in the dinghy, the largest 'container' available, that there was enough for every member of the crew to have a real binge!

Perhaps wooden vessels were used until the very large pottery jars were introduced in Minoan times? Believed to be storage containers for oil and for grain, these are usually called 'storage jars'; the way they are arranged, half buried in the floor in subterranean rooms where the temperatures would have been more or less constant, and in orderly rows, where the vessels could be filled directly from the press with the aid of wooden tubes, suggests that they were actually the vessels in which the grape juice was fermented. Jars of the same size, half-buried in rows in deep cellars, have been used until quite recently in Spain and in South America for fermenting grape juice (and may still be used).

Unfortunately the pips and the pollen of early forms of cultivated Vitis vinifera can hardly be separated from those of wild grapes (Vitis sylvestris), at least not with any degree of certainty. The earliest European wine may have been, and probably was, made of wild grapes, just as the first olive oil was undoubtedly pressed from wild olives. But the population increase attested by the great number of new settlements on soils unsuitable for the cultivation of cereals was undoubtedly caused by the sudden introduction of entirely new cultivars which could be grown on land previously impossible to exploit.

\section{Transporting and storing grapes and wine}

But how were the grapes transported, how were they crushed and how was the juice transported

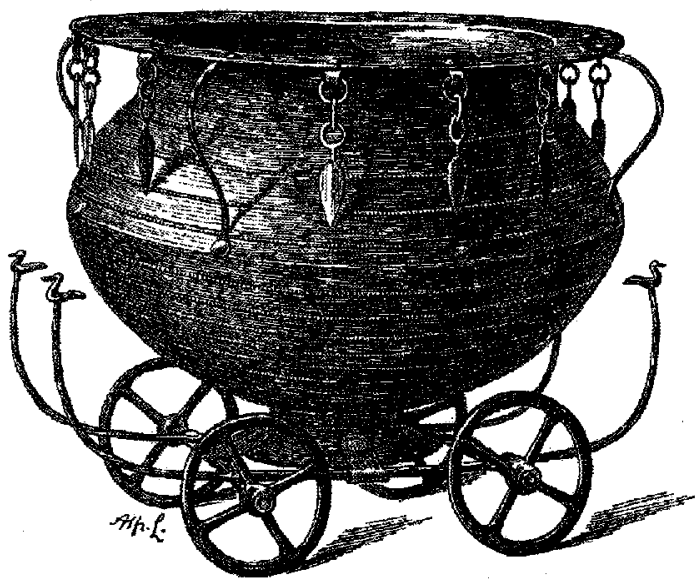

FIGURE 2. The wheeled cauldron from Skallerup. (From Broholm 1952: vol. III, figure 335a.)

and fermented, how was the final product, the wine, packed and distributed?

Any liquid, powdered or granulated product can flow, exerting hydrostatic pressure in all directions - and a reasonably great amount of ripe grapes will partly 'crush themselves' to form a soggy, semi-liquid mass. To contain such a product the vessel employed should, optimally, be spherical or approximately spherical, as are, indeed, all modern containers designed for such a purpose. The special railway cars used for hauling sugar or cement are usually fitted with two spherical containers each, whereas 'tank cars', such as are used for oil, milk, sulphuric acid or wine, usually have a cylindrical tank with hemispherical ends. The ordinary beercan, familiar to most archaeologists, is cylindrical with an inversely partly spherical bottom and an approximately spherical top.

A spherical or approximately spherical container would be optimal, such as a liquid-proof bag; it seems likely that early viticulturists actually used such leather bags, mounted on drays, to transport the grapes from the fields to the presses. FIGURE 1 (Arbejdsmark 1970: 36) shows a vehicle of a type used all over the world, in this case carrying a large basket of copra. Such a vehicle with a similar basket would have been ideal for transporting grapes, had the container only been liquid-proof - and so it could easily be, if the basket were provided with a leather lining. We can suppose that the earliest viticulturists used vehicles of this kind. We also assume that they switched to their ordinary farm 

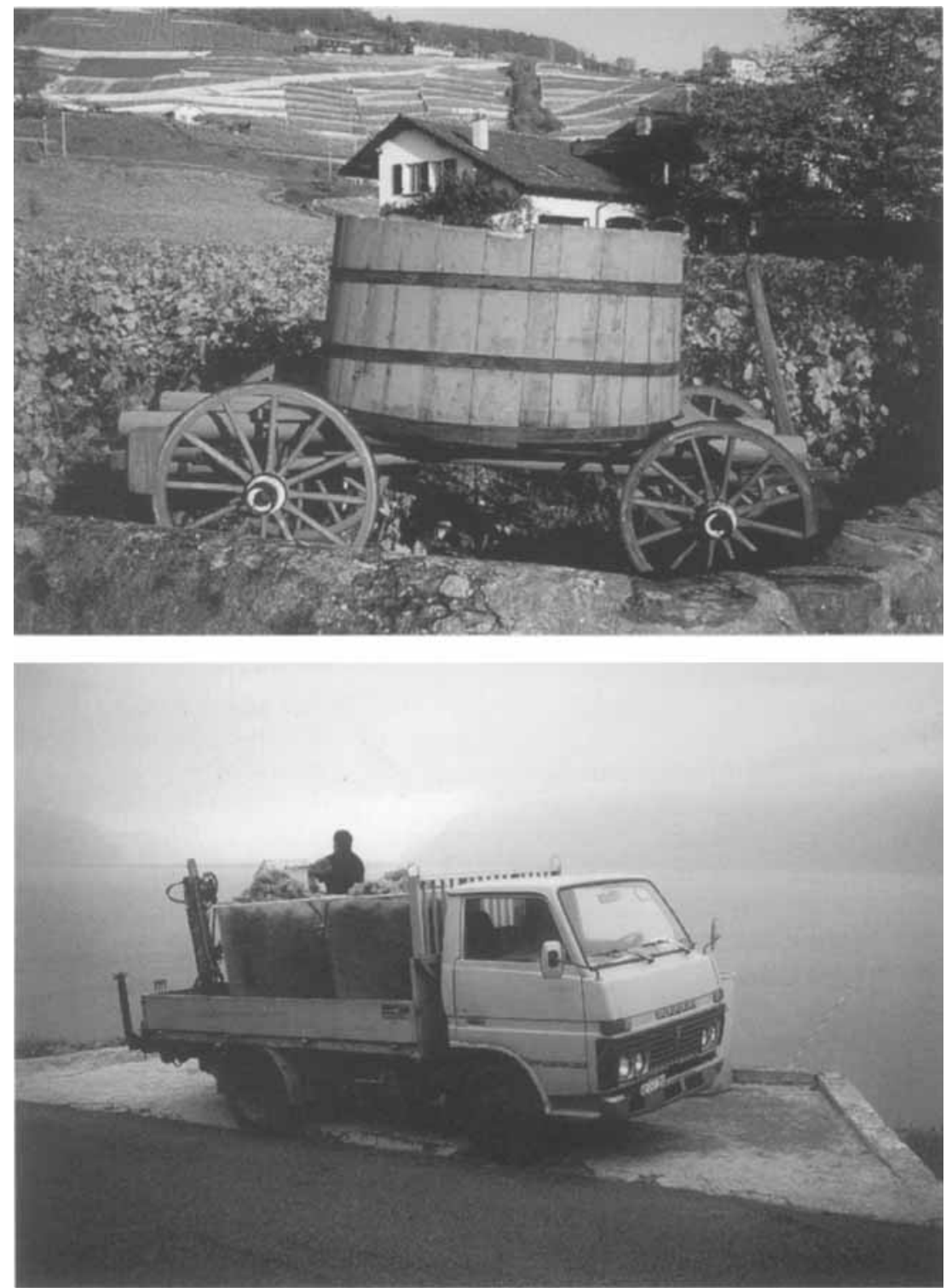

FIGURE 3. Wagon with stave-built wooden vat.

FIGURE 4. Lorry with vats of glass-fibre reinforced plastic. wagons for transporting their very heavy baskets as soon as local 'roads' were built, permitting wheeled vehicles to be used.

Those wagons were the patterns for bronze model wagons such as we know from Milavec, Peccatel, Skallerup, Ystad and Acholshausen (FIGURE 2). When coopering was invented, sometime in La Tène times, the basketry-reinforced leather bag was replaced by large stave-built barrels or vats.

Wagons, pulled by horses or by oxen (FIGURF 3), have been used until quite recently; they have been replaced by motor vehicles with plas- tic containers only in the last generation - but the principle remains the same (FIGURE 4)!

These 'kettle-wagons' all bear the head of a duck or a goose as their special sign. (None has the deer or the horsemen of the Strettweg vehicle, which is of course not a 'kettle-wagon' proper.)

The frame of the real kettle-wagon, the 'chassis' itself, often represents two ships. It is conceivable that also real wagons had frame-beams which, for some functional reason, were shaped like those of these model wagons, like the stems of real ships. In more recent times the frames 
of sledges have sometimes had this shape.

What purpose did these wheeled cauldrons serve? Maybe they were actually used at some drinking ceremony or 'drink sacrifice' not only in Central Europe but also in Scandinavia or were they perhaps blasphemously used at Norse drinking parties, simply as 'status symbols', imported from afar?

In many cultures inebriation has been seen as a divinatory stage; it is not unlikely that Dionysios or some god with duties like his Indo-European or not - may have been worshipped in Scandinavia already at an early time. We do not know whether the average Scandinavian of the time ever had an opportunity of tasting wine; even the earliest Scandinavians probably enjoyed fermented birch-juice, which is a pleasant though potent drink. At the moment we do not know when 'beer' was first brewed in Scandinavia, i.e. a drink based on starch which had been converted into sugars with the aid of $\alpha$-amylase and $\beta$-amylase, both natural enzymes. The oft-quoted find from Egtved consisted of the remains of a drink brewed on honey, spiced with berries and herbs, and was thus an early form of mead. Any Scandinavian bronze-buyer travelling in central Europe would undoubtedly have enjoyed the local wines and become a devoted servant of the wine-god!

Did such men bring home the wheeled cauldrons found at Skallerup, Ystad, Milavec, Peccatel and Acholshausen simply to impress their neighbours, or did they do so in order to serve this new god in their home- land? And, if so, was wine known and produced in Scandinavia at the time, did the wine-god insist on wine, or did he learn to enjoy mead?

\section{References}

ANER, E. \& K. KERSTEN. 1976. Die Funde der älteren Bronzezeit des Nordischen Kreises in Dänemark, Schleswig-Holstein und Niedersachsen II. Copenhagen: Verlag Nationalmuseum.

ARBEIDSMARK. 1970. Danish National Museum Yearbook 1920. Copenhagen.

BADLER, V.A. 1990. Drink and be merry! Infrared spectroscophy and ancient Near Eastern Wine, in Biers \& McGovern (1990): 176.

Biers, W.R. \& P.E. MCGOVERN. 1990. Organic contents of ancient vessels; materials analysis and archaeological investigation. Philadelphia [PA]: University Museum of Archaeology and Anthropology. MASCA Research Papers in Science and Archaeology 7.

Broholm, H.C. 1952. Danske Oldsager. Äldre Bronzealder. Copenhagen.

Cullen, T. \& D.R. KELLER. 1990. The Greek Pithos through time; multiple functions and diverse imagery, in Kingery (ed.).

DiCKINSON, O. 1994. The Aegean Bronze Age. Cambridge: Cambridge University Press.

EinseT, J. \& C. PratT. 1975. Grape vine, in J. Janick \& N. Moore, Advances in fruit breeding: 130-55. Lafayette (IN): Purdue University Press.

FlORIN, S. 1958. Vråkulturen. Stenåldersboplatserna vid Mogetorp, Östra Vrå och Brokvarn. Stockholm: Almqvist \& Wiksell.

HANSEN, J.M. 1988. Agriculture in the prehistoric Aegean: data versus speculation, American Journal of Archaeology 92: $39-52$.

HJELMQVTST, H. 1955. Die älteste Geschichte der Kulturpflanzen in Schweden, Opera Botanica 1: 3.
JONES, G. \& A. LEGGE. 1987. The grape (Vitis vinifera L.) in the Neolithic of Britain, Antiquity 61: 452-5.

KINGERY, W.D. 1990 The changing role of ceramics in society: $26000 \mathrm{BP}$ to the present. Westerville $(\mathrm{OH}):$ American $\mathrm{Ce}-$ ramic Society. Ceramics and Civilization 5.

MCGOVERN, P.E. et al. 1995. The origin and ancient history of wine. Luxemburg: Gordon \& Brcach.

MiKKELSEN, V. 1949. Praestö Fjord, Dansk Botanisk Arkiv 13: 5.

OLMO, H.P. 1995. The origin and domestication of the Vinifero grape, in McGovern et al. (1995).

Pescheck, C. 1975. Acholshausen, Landkreis Würzburg. Fürstengrab der Urnenfelderzeit, urn 1000 v. Chr., in G Biegel (ed.), Kölner Römer Illustrierte. Cologne.

PHILLIPS, P. 1975. Early farmers of west mediterranean Europe. London: Methuen.

RAUSING, G. 1990. Vitis pips in Neolithic Sweden, Antiquity 64: $117-22$.

RENFREW, J.M. 1973. Palaeoethnobotany: the prehistoric food plants of the Near East and Europe. London: Methuen.

SCHIEMANN, E. 1958. Die Pflanzenfunden in den neolithischen Siedlungen Mogetorp, Östra Vrå und Brokvarn, in Florin (1958): 253-300.

SGHUTZ, H. 1983. The prehistory of Germanic Europe. New Haven (CT): Yale University Press.

TROELS-SMTH, J. 1944. Fund av Vitis silvestris pollen i Danmark, Dansk Geologisk Forening 10.

ZOHARY, D. 1995. The domestication of the grapevine Vitis vinifera $\mathrm{L}$. in the Near East, in McGovern et $\alpha 1$. (1995).

ZOHARY, D. \& M. HOPF. 1988. Domestication of plants in the old World. Oxford: Clarendon.

ZOHARY, D. \& P. SPIEGEL-ROY. Beginning of fruit growing in the old World, Science 187: 319-27. 